Agro-Science Journal of Tropical Agriculture, Food, Environment and Extension Volume 9 Number 1 January 2010 pp. $64-69$

ISSN 1119-7455

\title{
STUDIES ON THE FUNGAL FLORA OF GARRI, PROCESSED CASSAVA (Manihot esculentus CRANTZ) IN NSUKKA AREA OF SOUTHEASTERN NIGERIA
}

\author{
Onyeke $^{1}$, C. C., Eze ${ }^{2}$, S. C. and Ugwuoke ${ }^{2}$, K. I. \\ ${ }^{1}$ Department of Botany, University of Nigeria, Nsukka, Nigeria. \\ ${ }^{2}$ Department of Crop Science, University of Nigeria, Nsukka, Nigeria.
}

\begin{abstract}
In Nsukka area of southeastern Nigeria, garri is usually displayed in the open market for sale which no doubt exposes the food stuff to dust particles from moving vehicles, wind and other sources. Thus, fungal spores from the air and soil environment could serve as major sources of fungal contamination of this product. Two garri types (white and yellow) were therefore sampled from six popular markets in the area which included Ogige, Nkwo-Ibagwa, Orie-Orba, Orie-Igboeze, EkeOzzi and Obollo-Afor markets. These samples were investigated for the presence of various species of fungi. Fungal isolates observed were: Aspergillus foetidus Thom and Raper, Aspergillus niger van Tiegh, Aspergillus sp., Penicillium sp., Rhizopus sp. and Candida sp. The fungal isolates occurred at varying frequencies, with A. foetidus being the most frequently isolated in both white and yellow garri while A. niger had the least occurrence in both white and yellow garri. Comparatively, white garri had higher frequency of occurrence of fungal organisms than yellow garri. Food processors are therefore, advised to always clean and sanitize equipment coming in contact with food to reduce microbial contamination and also to avoid other unhygienic handling of locally marketed foods.
\end{abstract}

Key words: Garri, Processed Cassava, Fungal Flora, Marihot esculemta

\section{INTRODUCTION}

Nigeria is the largest producer of cassava in the world, with a total production of 34 million metric tones annually (FAO, 2004). Cassava is a cheap and reliable source of carbohydrate for more than 700 million people in the developing world (FAO, 2003). In Nigeria, cassava supplies about $75 \%$ daily calorie intake to over 50 million Nigerians in cassava growing zones (Ugwu et al., 1993).

Cassava roots have been reported to have reasonable quantities of dietary fibre, potassium, phosphate, magnesium, calcium, riboflavin, thiamin, nicotinic acid, citrate, with low iron and vitamin contents (Bradbury and Holloway, 1998). The cassava roots deteriorate physiologically 2-5 days after harvest followed by microbial deterioration later (Rickard and Coursey, 1981). An economic way to deal with some of the rapid post harvest deterioration is through processing. Processing reduces the bulkiness; transportation cost, and extends the shelf life of cassava products. However, the vast majority of cassava roots are processed in the villages by a variety of small scale methods into many different products that cater for the local preferences and for industrial use.

The popular form in which cassava is eaten in West Africa is in a fermented granulated form known as 'Garri' (Okpokiri et al., 1985; Ofuya and Akpoti, 1988). Garri could be consumed both as a major meal (when soaked in boiled water to form a thick paste and swallowed with choice soup or stew) and as a minor meal (when soaked in cold water and eaten with roasted peanut, coconut or dried fish (Ogiehor and Ikenebomeh, 2006).

Contamination of cassava and cassava products by fungal organisms has serious health implications as some potent toxins (Ochratoxin A, Zearalenone, Scopoletin, Patulin, Sterigmatocystin, Penicillic acid etc) have been detected (Bottalico et. al., 1980, Soares and Rodriguez-Amaya, 1989). Given the health implication of post-harvest fungal deterioration of cassava products, it becomes necessary to provide baseline information on the types of fungal flora associated with these products in an area to ascertain the potential 
hazard to which consumers are exposed. identify fungal flora associated with garri in Nsukka area and to determine which type of garri (white or yellow) that least supports fungal contamination.

\section{MATERIALS AND METHODS Sample Collection}

Sixty samples of garri were collected from the six major markets in Nsukka area. Five samples each of white and yellow garri were randomly collected from each market. The markets were, Ogige, Nkwo-Ibagwa, Orie-Orba, Orie-Igboeze, Eke-Ozzi and Obollo-Afor markets. The samples were aseptically collected from different sellers randomly in sterile polythene bags as recommended by AbbaKareem et al. (1990). The samples were immediately taken to the laboratory for isolation and identification of fungi.

\section{Isolation of Fungi}

Two grams of each garri sample was weighed using analytical weighing balance and added to $10 \mathrm{ml}$ of sterile distilled water in a test tube. The content was then thoroughly shaken by hand for about two minutes. The serial single fold dilutions of the suspensions from $10^{-1}$ to $10^{-}$ 4 were made. One $\mathrm{ml}$ of each dilution was transferred aseptically into separate Petri dishes containing potato dextrose agar (PDA) using a sterile pipette and then spread over the surface using a glass spreader, which has been immersed in alcohol and flamed (Flint, 1985). Each dilution was plated in triplicate. The plates were then examined after a period of 4-7 days for the presence of fungal colonies. After the incubation period, the various colonies were sub-cultured in fresh sterilized PDA to obtain pure cultures for proper characterization and identification.

\section{Characterization and Identification of Fungal Isolates}

The number of colonies of each fungus in each culture of PDA was obtained by counting by sight with a tally counter. The isolates were mounted on slides stained with cotton blue in-lacto phenol and covered with cover slips and observed under a binocular research microscope. Identification and characterization was based on cultural, morphological and description in existing literature (Samson et. al., 1984; Barnett and Hunter, 1987).
Therefore, the present study was designed to Data Analysis

All data collected were subjected to analysis of variance (ANOVA) using Statistical Analysis System (SAS), version 9. Means were separated by the least Significant Difference (LSD) and the graphs were drawn using Microsoft Excel Chart Wizard.

\section{RESULTS}

The microphotographs of the fungal isolates are shown in Figure 1. Aspergillus spp. constitutes the commonest group of microorganisms on processed garri in Nsukka area.

Large colonies of fungi were obtained on white garri in all the sampled locations with Obolloafor having the highest number of colonies while Ogige market had significantly $(\mathrm{P} \leq 0.05)$ the least number of colonies (Table1). Among the fungal isolates, A. foetidus on the average had significantly $(\mathrm{P} \leq 0.05)$ greater number of colonies on white garri while A. niger had the least. The combined effects of location and fungal isolates on the colony size showed large and significant colony size of Penicillium sp. on white garri at Obollo-afor market. Colony size of Penicillium sp. on white garri varied significantly $(\mathrm{P} \leq 0.05)$ across the locations except at Nkwo-Ibagwa and Orie-Orba markets where the sizes were statistically the same with Aspergillus sp.

Similarly, fungal colonies on yellow garri varied significantly across all the market locations (Table 1). On the average, A. foetidus produced the highest number of colonies while A. niger had the least. The combined effects of location and fungal isolates on yellow garri were similar to that of white garri except that the highest number of colonies occurred at OrieIgboeze market while the least was at Orie-Orba market.

Generally, the activities of fungi in terms of fungal colonies were highest on white garri while yellow garri produced the least number of colonies in all the sampled locations as shown in Figure2. Nkwo-Ibagwa and ObolloAfor markets produced the highest number of fungal colonies on white garri while Ogige and Orie-Orba markets had the least number of colonies on both white and yellow garri.

Among the fungal isolates, A. foetidus significantly $(\mathrm{P} \leq 0.05)$ produced the highest number of colonies while A. niger recorded the least number of colonies on the two colour types of garri (Figure 3). Colonies of Rhizopus sp. on the two colours of garri were different but the differences were not significant $(\mathrm{P} \geq 0.05)$ as was observed in other fungal isolates. 


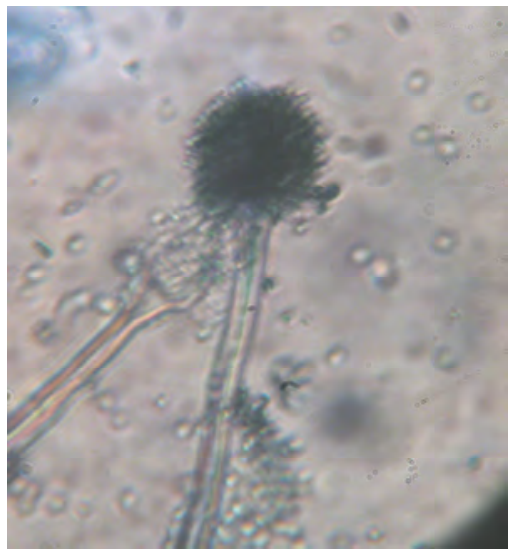

(a) Aspergillus foetidus

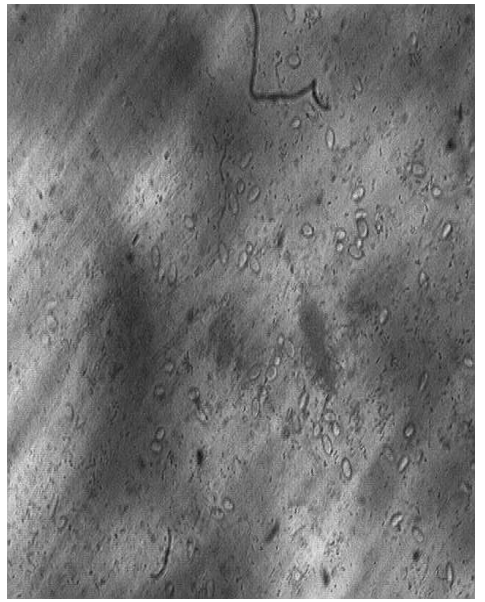

(d) Candida sp.

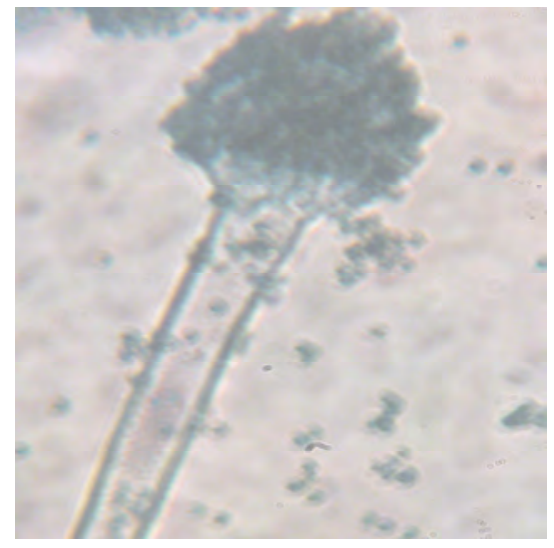

(b) Aspergillus niger

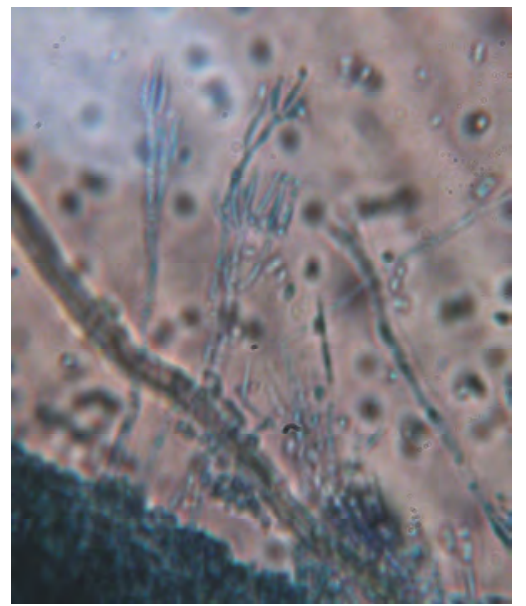

(e) Penicillium sp.

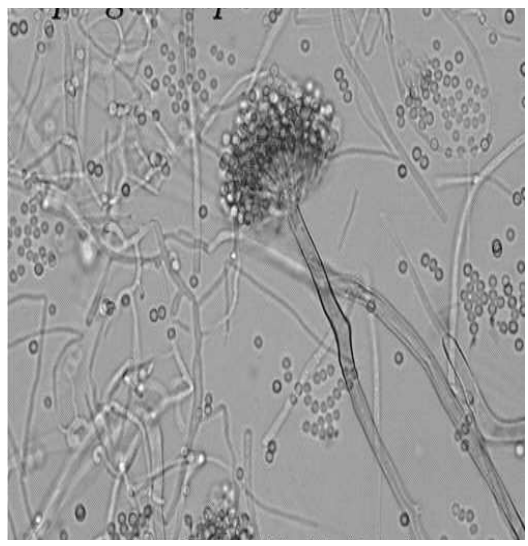

(c) Aspergillus $S P$

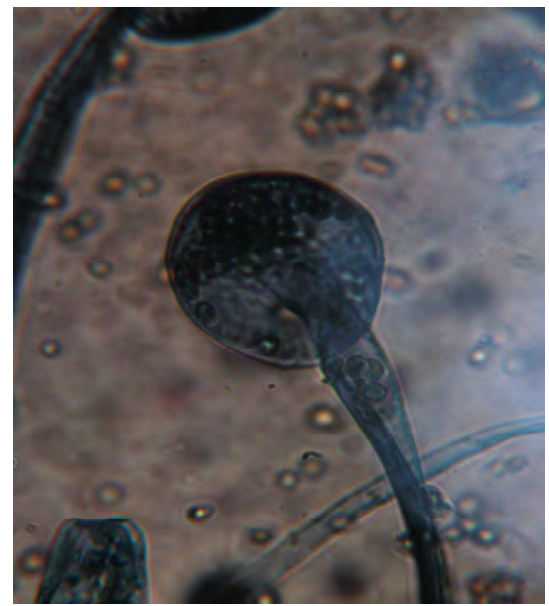

(f) Rhizopus sp.

Figure 1 (Plates a-f): An array of microphotographs of the fungal organisms found on the processed garri

Table 1: Fungal isolates and number of colonies in both white and yellow garri from different markets sampled.

\begin{tabular}{|c|c|c|c|c|c|c|c|c|}
\hline \multirow[b]{2}{*}{$\begin{array}{l}\text { Types of } \\
\text { garri }\end{array}$} & \multirow[b]{2}{*}{ Fungal Isolates } & \multicolumn{5}{|c|}{ Market locations and number of fungal colonies } & \multirow[b]{2}{*}{$\begin{array}{l}\text { Orie- } \\
\text { Orba }\end{array}$} & \multirow[b]{2}{*}{ Mean } \\
\hline & & $\begin{array}{l}\text { Eke- } \\
\text { Ozzi }\end{array}$ & $\begin{array}{l}\text { Nkwo- } \\
\text { Ibagwa }\end{array}$ & $\begin{array}{l}\text { Obollo- } \\
\text { Afor }\end{array}$ & Ogige & $\begin{array}{l}\text { Orie- } \\
\text { Igboeze }\end{array}$ & & \\
\hline \multirow{7}{*}{ White garri } & Aspergillus foetidus & 8.40 & 9.77 & 8.63 & 5.07 & 8.40 & 5.06 & 7.56 \\
\hline & Asppergilus niger & 2.92 & 2.35 & 3.24 & 2.92 & 2.92 & 2.35 & 2.78 \\
\hline & Aspergillus sp. & 3.24 & 3.24 & 3.37 & 2.92 & 2.92 & 2.55 & 3.04 \\
\hline & Candida sp. & 6.13 & 0.70 & 3.52 & 1.86 & 0.69 & 6.74 & 3.29 \\
\hline & Penicillium sp. & 5.15 & 7.39 & 10.46 & 6.20 & 5.88 & 3.81 & 6.48 \\
\hline & Rhizopus sp. & 0.70 & 5.52 & 6.36 & 0.73 & 4.73 & 3.23 & 3.55 \\
\hline & Mean & 4.42 & 4.83 & 5.93 & 3.30 & 4.26 & 3.96 & 4.45 \\
\hline \multirow{11}{*}{ Yellow garri } & Aspergillus foetidus & 4.53 & 2.29 & 4.37 & 2.55 & 5.15 & 1.58 & 3.52 \\
\hline & Asppergilus niger & 2.35 & 1.58 & 2.23 & 1.22 & 1.68 & 0.71 & 1.46 \\
\hline & Aspergillus sp. & 2.35 & 1.59 & 1.22 & 0.71 & 2.55 & 0.70 & 1.52 \\
\hline & Candida sp. & 3.66 & 0.71 & 0.71 & 1.57 & 3.07 & 1.86 & 1.93 \\
\hline & Penicillium sp. & 2.12 & 8.81 & 3.24 & 2.74 & 5.25 & 1.58 & 3.12 \\
\hline & Rhizopus sp. & 3.33 & 3.94 & 3.94 & 3.08 & 3.44 & 0.73 & 3.06 \\
\hline & Mean & 3.06 & 2.43 & 2.45 & 1.98 & 3.51 & 1.19 & 2.43 \\
\hline & & & & & & & $\begin{array}{l}\text { White } \\
\text { garri }\end{array}$ & $\begin{array}{l}\text { Yellow } \\
\text { garri }\end{array}$ \\
\hline & \multirow{3}{*}{\multicolumn{6}{|c|}{$\begin{array}{l}\operatorname{LSD}(0.05) \text { for comparing any two location means } \\
\operatorname{LSD}(0.05) \text { for comparing any two fungal isolates means } \\
\mathrm{LSD}(0.05) \text { for comparing any two location } \mathrm{x} \text { fungal isolates means }\end{array}$}} & 0.32 & 0.09 \\
\hline & & & & & & & 0.32 & 0.09 \\
\hline & & & & & & & 0.78 & 0.22 \\
\hline
\end{tabular}




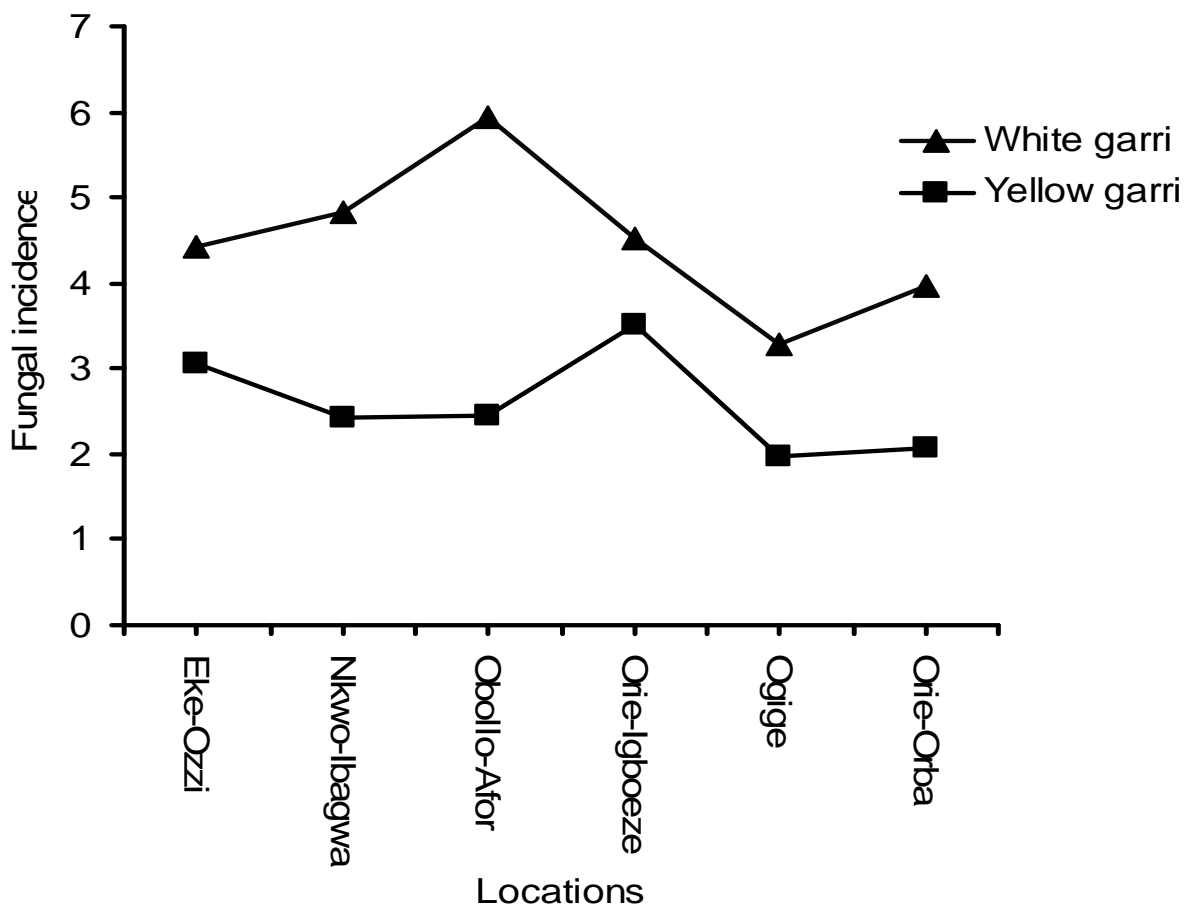

Figure 2: Influence of colour and location on fungal incidence on consumable garri.

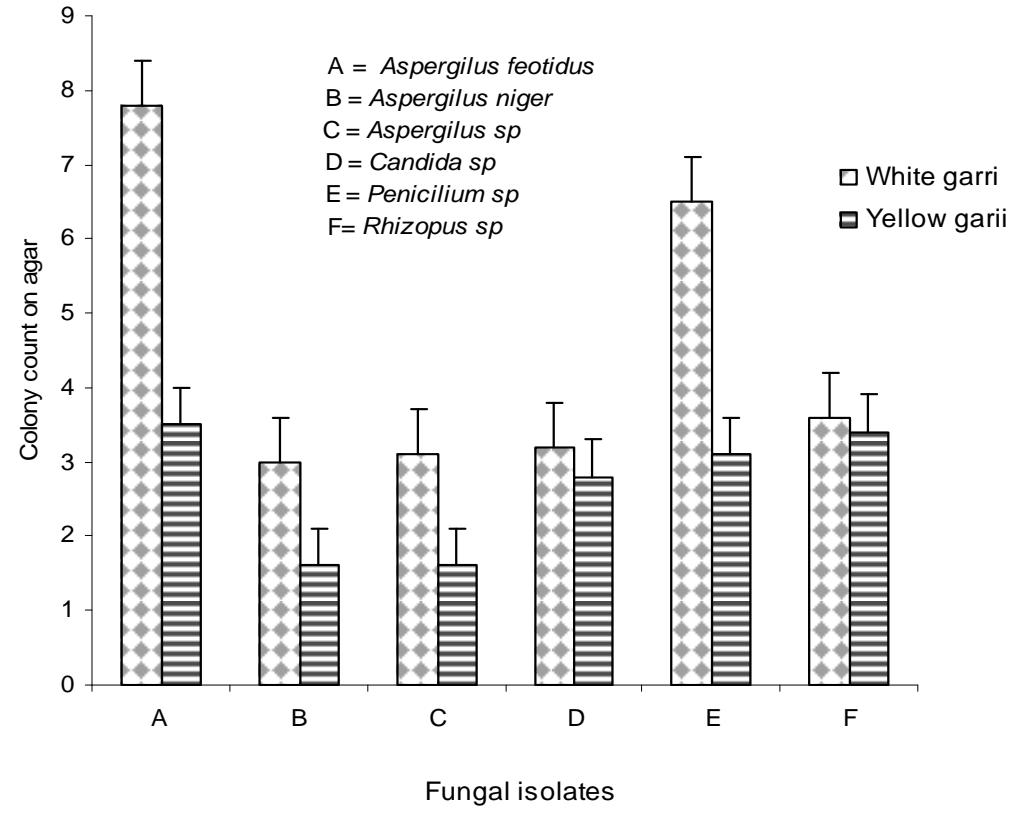

Figure 3: Fungal isolates and size of colonies on white and yellow garri in the study areas. 


\section{DISCUSSION}

Fewer colonies were obtained from yellow garri compared to that of white garri as was shown in this study. This could be due to the presence of palm oil that gave it the yellow colour and served as preservative and therefore, reduced emergence of fungal colonies suggesting that palm oil has anti-fungal properties (Hahn, 1989). In fact, certain plantbased oils have been reported to have antifungal activity (Reuveni et al., 1984; Baruah et al., 1996). Dubey and Kishore (1988) observed that essential oils from Mealeuca leucadendron, Ocimum canum and Citrus medica were able to protect several stored food commodities from biodeterioration caused by Aspergillus flavus and Aspergillus versicolor. Akueshi et. al. (1998) stated that properly fried garri could stay for more than one year without deterioration. It is therefore, possible that yellow garri when properly fried should store for longer period of time without getting heavily colonized by microorganisms than white garri. The high occurrence of a number of fungal species obtained during this survey is in agreement with the report by Frazier and Westhoff (1988), which stated that fungi are common contaminants in food stuffs.

There is a high incidence of a number of fungal species such as A. foetidus in both garri types. This result is supported by the findings of Rayman et al. (1975) who reported that a number of food items sold locally have been shown to be highly contaminated with fungal species especially Aspergillus sp. The presence of some fungal organisms in both garri types could be that handlers may have introduced them into the garri types due to unhygienic practices (Frazier and Westhoff, 1988). In the market places (outlets) both white and yellow garri are usually exposed to dust particles from moving vehicles, winds and other sources. Thus, the fungal spores from the air and soil environment could serve as major sources of fungal contamination of these food stuffs. Okodugha and Obanu (1989) also reported that poor sanitary conditions in most of the local markets and environment being highly polluted and charged with spoilage and pathogenic flora are likely to be source of contamination of food items sold in such markets. Some fungal contamination of these garri types could also be from materials used for their storage and from milling equipment.

The high occurrence of the fungal genera such as Aspergillus sp, Penicillium sp, Rhizopus sp. and Candida sp. in both garri types may be because they are highly distributed in nature and also for their ability to use many commodities as substrates. Thus, they are among the most common organisms involved in food spoilage as observed in this study and are potential producers of mycotoxins (eg. aflatoxins etc.) toxic to humans and animals (Frazier and Westhoff, 1988). Consumption of aflatoxigenic food commodities by man can lead to acute aflatoxicosis. In fact, ingestion of aflatoxincontaminated food has been reported to be a synergistic factor in the development of several diseases as Reye's syndrome, liver cell cancer and Hepatitis B (CAST, 1989). Adhikari et al. (1994) observed that aflatoxins also have immunosuppressant properties. Etim (1985) stated that in developing countries like Nigeria, the need for improved preparation, processing, preservation and storage techniques as a way of enhancing food standards for indigenous and locally consumed food cannot be over emphasized. Therefore, there is need for food processors to attempt to clean and sanitize equipment coming in contact with food to reduce microbial contamination and also to avoid other unhygienic handling of locally marketed foods. It has been reported that with a moisture content of $16 \%$ or less, aflatoxin production was not likely, but $17 \%$ may be high enough for growth and aflatoxin production (Trenk and Hartman, 1970). Garri processors should ensure that their products have very low moisture content before sale to limit fungal growth and subsequent aflatoxin production. Presence of oil in yellow garri discouraged germination and sporulation of fungal organisms and consequently can limit aflatoxin synthesis in foodstuff. Yellow (oiled) garri are generally less prone to fungal contamination, and is therefore safer for human consumption.

\section{ACKNOWLEDGEMENT}

The authors are very grateful to $\mathrm{Mr}$. John Ezema of the Mycology/plant pathology unit of the Department of Botany, University of Nigeria, Nsukka for his invaluable services in the identification the fungal organisms.

\section{REFERENCES}

Abbakareem,V.N., Okagbue, R. N. and Ogbadu, G.H.(1990). The production of aflatoxin by Aspergillus flavus in cassava flour Nigerian Food Journal, 8:86-91.

Adhikari, M., Ramjee, G. and Berjak, P. (1994). Aflatoxin, Kwashiokor and Morbidity. Natural Toxins 2: 1-3.

Akueshi E. U.,Akujobi E., Ekwenchi, M. M. and Iledare, M. F. (1998). Lead levels in cassava flour dried by the high way. African Journal of Natural Science 1 (1): 46-47. 
Alankararao, G.S.J.G., Baby, P., Rajendra, P.Y. (1991). Leaf oil of Coleus amboinicus Lour: the in vitro antimicrobial studies. Perfumerie Kosmetics 72: 744-745.

Barnett, H.L. and Hunter, B.B. (1987). Illustrated genera of imperfect fungi. MacMillian Publishing Company, New York, 218pp.

Baruah,P., Sharma, R.K., Singh, R.S. Ghosh, A.C.(1996). Fungicidal activity of some naturally occurring essential oils against Fusarium moniliforme. Journal of Essential Oil Research 8: 411-441.

Bottalico, A., Lerario, P. and Frisullo, S. (1980). Presenza di aflatossine, di zearalenone e di ceppi di Aspergilli prouttori di aflatossine in campioni di farina di mandioca. Zootecnia e Nutrizione Animale 6: 209-214.

Bradbury, J.H. and Holloway, W.D. (1998). Chemistry of tropical root crops: significance for nutrition and agriculture in pacific. ACIAR monograph no 6, Australian centre for international agriculture, Canberra.

CAST (1989). Mycotoxins : economic and health risks. Task Force Report 116, 91pp.

Dubey, N.K. and Kishore, N. (1988). Exploitation of higher plant products as natural fumigants. In: proceedings of the fifth international congress on plant pathology, Kyoto, Japan, p. 423 (abstract)

Etim, E. E. (1985). Enhancement of demand for indigenous locally consumed food through improved processing, preservation, presentation and storage techniques. Nigerian Food Journal, 3: 41-45.

Flint, K.P. (1985). A note on a selected agar medium for the enumeration of Flavobacterium species in water. Journal of Applied Bacteriology, 50: 561-566.

Frazier, W.C.and Westhoff, D.C. (1988). Food microbiology $\left(4^{\text {th }}\right.$ edition). MacGraw Hill, New York. 53pp.

Food and Agricultral Organization FAO (2003). FAOSTAT, FAO statistical data base Agriculture.

Food and Agricultral Organization FAO (2004). FAOSTAT, FAO statistical data base Agriculture.

Hahn, S. K. (1989). An overview of African traditional Cassava Processing and Utilization. Outlook on Agriculture 18 (3): 110-118.
Ofuya, C.O. and Akpoti, P. (1988). Post processing microflora and shelf stability of garri. Journal of Applied Bacteriology 64:389-394.

Ogiehor, I.S. and Ikenebomeh, M.J. (2006). The effects of different packaging materials on the shelf stability of garri. African Journal of Biotechnology 5(23):24122416.

Okodugha, S. A and Obanu, A. (1989). Effects of description processing on micro flora of raw beef. Nigerian Food Journal 7: $39-49$.

Okpokiri, A.O.,Ijioma, B.C., Alozie, S.O. and Ejiofor, M.A.N.(1985). Production of improved cassava "fufu". Nigerian Food Journal 7:39-49.

Rayman, M.K., Park, C.E., Philpott, J. and Todd, E.C. (1975). Re-assessment of the coagulase and thermonuclease tests as means of identifying Staphylococcus aureus. Applied Microbiology 29: 451454.

Reuveni, R., Fleischer, A.,Putievski, E.(1984). Fungistatic activity of essential oils from Ocimum basilicum chemotypes. Phytopathologische Zeistschrift 10:2022.

Rickard, J. E. and Coursey, D. G. (1981). Cassava storage, Part 1: Storage of fresh cassava roots. Tropical Science 23: 1-32.

Samson, R.A., Hoekstra, E., Connie, A.W. and Van Oirschot,Q. (1984). Introduction to food borne fungi. Institute of the Royal Academy of Arts and Science, Netherlands.307pp.

SAS Institute (1999). SAS/STAT user's Guide, release 6.12. SAS Institute.

Soares, L.M.V. and Rodriguez-Amaya, D.B.(1989). Survey of aflatoxins, ochratoxin A, zearalennone, and sterigmatocystin in some Brazilian foods by using multi-toxin thin -layer chromatographic method. Journal of the Association of Official Analytical Chemists, USA 72: 22-26.

Trenk, H.L.and Hartman, P.A. (1970). Effects of moisture content and temperature on aflatoxin production. Applied Microbiology, 19: 781-784.

Ugwu, B. O., Ajabo, O and Orkwor, G. C (1993). Cassava research, production and utilization in Nigeria. Product Development for Root and Tuber Crops. 3: 55-56. International potato centre. Peru. 